\title{
APPLICATION OF LEARNING CELL STRATEGY TO IMPROVE POSING QUESTION IN SOCIAL STUDIES
}

\author{
Nurul Hidayati, Siti Wahyuningsih, Hadiyah \\ Universitas Sebelas Maret \\ nurulyusufi271@gmail.com
}

\section{Article History}

accepted 09/07/2018

approved 01/08/2018

published 17/09/2018

\section{Keywords}

learning cell strategy, posing question, social studies

\begin{abstract}
The purpose of this research is to improve the posing questions on social studies of third grade students elementary school. Methods of data retrieval is done by observation, interview, and documentation. Data collected are result of posing question observation, result of teacher and students interview and documentation of learning process. Data validity used are validity of content and triangulation of sources and methods. Data analysis using interactive models. The result of research is quantity of question in cycle I and cycle II in sequence that is 444 and 455 questions. The number of questioning students increased to $100 \%$ of students in the class or a total of 36 students. The quality of the questions indicated includes the cognitive thinking levels C1, C2, C3, and $\mathrm{C} 4$, whereas the dimensions of knowledge lie in the factual, conceptual, procedural, and metacognitive. Based on the results of research can be concluded that the application of learning cell strategy can improve the posing question.
\end{abstract}

Social, Humanities, and Education Studies (SHEs): Conference Series https://jurnal.uns.ac.id/shes 


\section{PENDAHULUAN}

Pembelajaran tidak lepas dari kegiatan tanya jawab. Tidak hanya guru yang bertanya kemudian siswa yang menjawab, tetapi kemampuan siswa dalam bertanya juga perlu ditingkatkan.Terutama pada mata pelajaran dengan berbagai disiplin ilmu dan kajian yang luas yaitu IImu Pengetahuan Sosial (IPS). Namun pada kenyataannya, pembelajaran IPS di jenjang sekolah dasar belum dilaksanakan secara maksimal oleh guru maupun siswa. Kurangnya interaksi multiarah berupa tanya jawab antara guru dan siswa menjadikan salah satu faktor kelemahan dalam pembelajaran IPS. Kelemahan ini dapat diminimalisir dengan mengembangkan keterampilan bertanya.

Keterampilan bertanya menurut Astuti (2015: 11) adalah cara penyampaian suatu pelajaran melalui interaksi dua arah yaitu dari guru ke siswa dan siswa ke guru agar diperoleh jawaban kepastian materi melalui keduanya. Daryanto (2014: 65) menjelaskan bahwa istilah 'pertanyaan' tidak selalu berbentuk kalimat tanya, tetapi juga dalam bentuk pernyataan asalkan kedua pihak menginginkan tanggapan verbal (lisan), sehingga guru membuka kesempatan secara luas dan terbuka kepada peserta didik untuk bertanya mengenai apa yang dilihat, dibaca, disimak maupun dipelajari. Nevers dan Melrose (2016: 1) melihat kegiatan bertanya melalui sudut pandang kontruktivisme, proses mengajukan pertanyaan dapat dianggap sebagai alat penting untuk melibatkan peserta didik dan mendukungnya menuju kesuksesan dalam perjalanan belajar pribadi mereka sendiri.

Hasil kegiatan observasi pra-siklus menunjukkan hanya 19,4\% atau 7 orang dari 36 siswa yang berani mengajukan pertanyaan dengan masing-masing siswa mengajukan 1 pertanyaan. Hal ini menunjukkan kuantitas siswa yang bertanya di kelas masih rendah. Kemudian kualitas pertanyaan yang diajukan terdiri dari beberapa tingkatan yakni: 4 pertanyaan faktual tingkat $\mathrm{C} 1,1$ pertanyaan faktual tingkat $\mathrm{C} 2$, dan 2 pertanyaan konseptual tingkat C2.

Berdasarkan hasil observasi pra-siklus di atas perlu dilakukan upaya peningkatan keterampilan bertanya. Usaha peningkatan keterampilan bertanya dapat dilakukan dengan strategi pembelajaran. Strategi pembelajaran learning cell efektif meningkatkan keterampilan bertanya dengan menarik minat dan antusias siswa ketika belajar. Strategi pembelajaran tersebut menuntun siswa secara lisan maupun tulisan untuk menyalurkan gagasan, ide, pendapat maupun pertanyaan yang dimiliki.

Strategi pembelajaran learning cell dijelaskan oleh Zaini (2008: 86) menunjuk pada bentuk belajar kooperatif dalam bentuk berpasangan, siswa bertanya dan menjawab pertanyaan secara bergantian berdasar pada materi pelajaran yang sama. Langkah-langkah strategi learning cell antara lain: 1) Guru memberi penjelasan singkat mengenai materi IPS yang dipelajari; 2) Guru membagi siswa menjadi kelompok berpasangan yang terdiri dari siswa A (penanya) dan siswa B (penjawab); 3) Masingmasing siswa membuat minimal dua buah pertanyaan mengenai materi/ media yang diberikan guru. (untuk meningkatkan kuantitas pertanyaan siswa); 4) Siswa A mengajukan pertanyaan kepada siswa B untuk dijawab. Apabila sudah terjawab, siswa B bergantian mengajukan pertanyaan kepada siswa A; 5) Guru bergerak dari satu pasangan ke pasangan lain sambil memberi masukan, jawaban, maupun pertanyaan dengan tingkatan lebih tinggi dari pertanyaan yang dihasilkan siswa. (untuk meningkatkan kualitas pertanyaan siswa).

Kelebihan strategi pembelajaran learning cell menurut Siregar (2012) meliputi: 1) membina kerjasama antar siswa; 2) meningkatkan aktivitas belajar; 3) suasana belajar menjadi menyenangkan; 4) meningkatkan rasa tanggung jawab. Strategi ini juga memberanikan siswa untuk bertanya kepada teman maupun gurunya. Selain itu menurut Barkley (2012: 211), cara ini akan memberikan kesempatan kepada siswa untuk berpikir analitis sambil mengubah materi ke dalam bentuk pertanyaan dengan kalimatnya sendiri. Menjawab pertanyaan yang diajukan temannya dapat memberi 
landasan pemahaman bagi diri siswa tersebut. Saling bertukar pertanyaan akan memotivasi siswa untuk berusaha mendapat pemahaman yang lebih dalam terhadap materi pelajaran IPS.

Berdasarkan uraian tersebut, peneliti melakukan penelitian dengan judul "Penerapan Strategi Pembelajaran Learning Cell untuk Meningkatkan Keterampilan Bertanya pada Pembelajaran IPS (Penelitian Tindakan Kelas pada Siswa Kelas III SD Negeri Karangasem II Surakarta Tahun Ajaran 2017/2018)." Peneliti juga menyusun rumusan masalah penelitian yaitu "Apakah penggunaan strategi pembelajaran learning cell dapat meningkatkan keterampilan bertanya pada pembelajaran IPS siswa kelas III di SD Negeri Karangasem II Surakarta tahun ajaran 2017/2018?" Sesuai dengan rumusan masalah tersebut, penelitian ini bertujuan untuk meningkatkan keterampilan bertanya melalui penerapan strategi pembelajaran learning cell pada pembelajaran IPS siswa kelas III di SD Negeri Karangasem II Surakarta tahun ajaran 2017/2018.

\section{METODE}

Penelitian ini berupa Penelitian Tindakan Kelas (PTK) yang dilakukan di SD Negeri Karangasem II Surakarta pada bulan Januari-Juni 2018. Subjek penelitian ini adalah siswa kelas III yang berjumlah 36 siswa, terdiri dari 20 siswa laki-laki dan 16 siswa perempuan. Semua siswa di kelas III memiliki kondisi fisik dan kejiwaan yang sehat, dengan kata lain tidak ada siswa yang cacat.

Teknik pengumpulan data yaitu melalui observasi, wawancara dan dokumentasi. Uji validitas data dilakukan dengan triangulasi sumber dan metode serta validitas isi. Penelitian ini menggunakan teknik analisis data model interaktif Miles dan Huberman (2014) yang terdiri dari tiga tahap, yaitu data reduction, data display, dan conclusion drawing/ verification.

Jayanti (2015) mengukur keterampilan menggunakan dua aspek, yaitu: kuantitas dan kualitas pertanyaan yang diajukan siswa. Indikator kinerja penelitian ini adalah peningkatan keterampilan bertanya siswa dalam mata pelajaran IPS dengan ketercapaian target $80 \%$ jumlah siswa di kelas meningkatkan 1 buah kuantitas pertanyaan dan 1 tingkat kualitas pertanyaan berdasarkan data baseline.

\section{HASIL DAN PEMBAHASAN}

Penelitian ini dilakukan selama 2 siklus. Masing-masing siklus terdiri dari 2 kali pertemuan dengan alokasi waktu $2 \times 35$ menit dan $1 \times 35$ menit. Materi yang dipelajari pada penelitian ini untuk siklus I yaitu jenis-jenis pekerjaan dan siklus II yaitu kegiatan jual beli.

Analisis data hasil observasi keterampilan bertanya pada kegiatan siklus I dan siklus II dapat dikatakan mengalami peningkatan yang signifikan dibandingkan pada kegiatan pra-siklus. Kuantitas pertanyaan pada kegiatan pra-siklus sejumlah 7 pertanyaan meningkat menjadi 444 pertanyaan di siklus I dan 455 pertanyaan di siklus II seperti yang ditampilkan pada Gambar 1 .

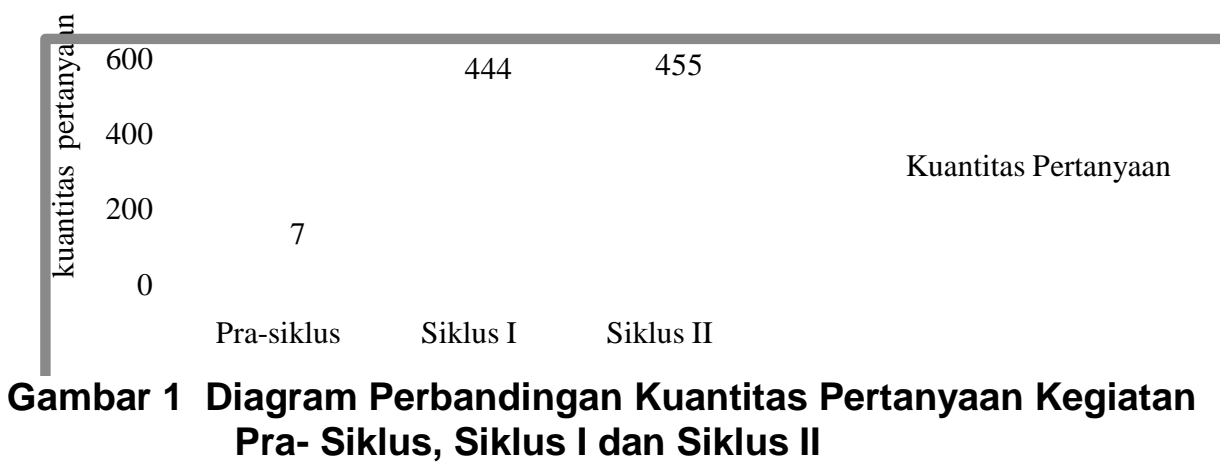

Pada kegiatan pra-siklus, siswa yang bertanya sejumlah 7 anak dengan masing-masing berkontribusi sebanyak 1 buah pertanyaan, sedangkan setelah 
dilakukan tindakan dengan menerapkan strategi pembelajaran learning cell pada siklus I dan siklus II jumlah siswa yang bertanya sebanyak 36 siswa. Masing-masing siswa memiliki kontribusi yang berbeda dalam mengajukan jumlah pertanyaan. Kuantitas pertanyaan yang diajukan masing-masing siswa dapat dilihat pada Gambar 2.

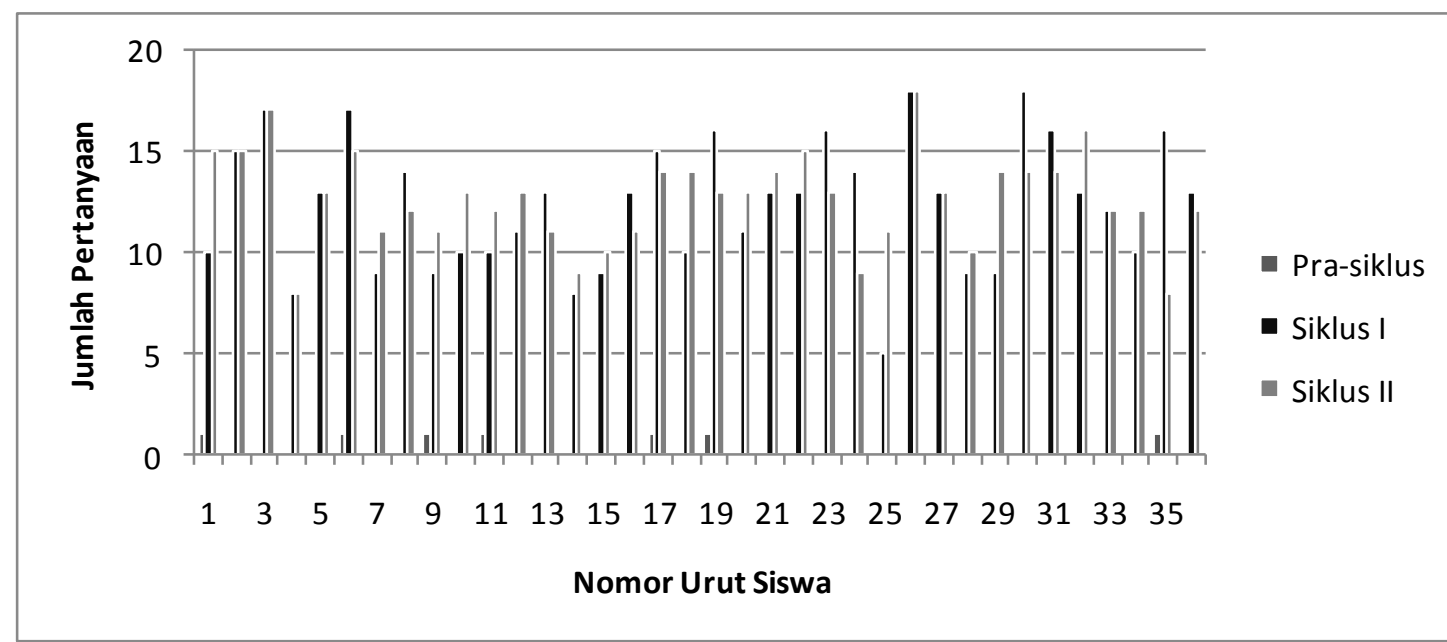

\section{Gambar 2 Grafik Perbandingan Kuantitas Pertanyaan yang Diajukan Tiap Siswa Pra-Siklus, Siklus I dan Siklus II}

Target capaian peningkatan 1 buah kuantitas pertanyaan untuk masing-masing siswa berdasarkan data baseline tercapai walaupun jumlah pertanyaan yang diajukan tiap siswa berbeda. Siswa yang memberikan kontribusi terhadap kuantitas perta-nyaan pada kegiatan pra-siklus yaitu siswa dengan nomor urut 1, 6, 9, 11, 17, 19, dan 35 tetap mengajukan pertanyaan meskipun mengalami peningkatan dan penurunan pada siklus I dan siklus II Presentase siswa yang ditargetkan untuk bertanya yaitu $80 \%$ dari 36 siswa juga sudah terpenuhi pada siklus I maupun siklus II dengan 100\% siswa di kelas mengajukan pertanyaan.

Peningkatan juga terjadi terhadap kualitas pertanyaan yang diajukan siswa. Kualitas pertanyaan pada dimensi pengetahuan faktual, konseptual, prosedural dan metakognitif mengalami peningkatan dari kegiatan pra-siklus ke siklus I dan siklus II. Perbandingan capaian kualitas pertanyaan yang diajukan siswa antara kegiatan prasiklus dengan kegiatan siklus I dan siklus II dapat dilihat pada Gambar 3.

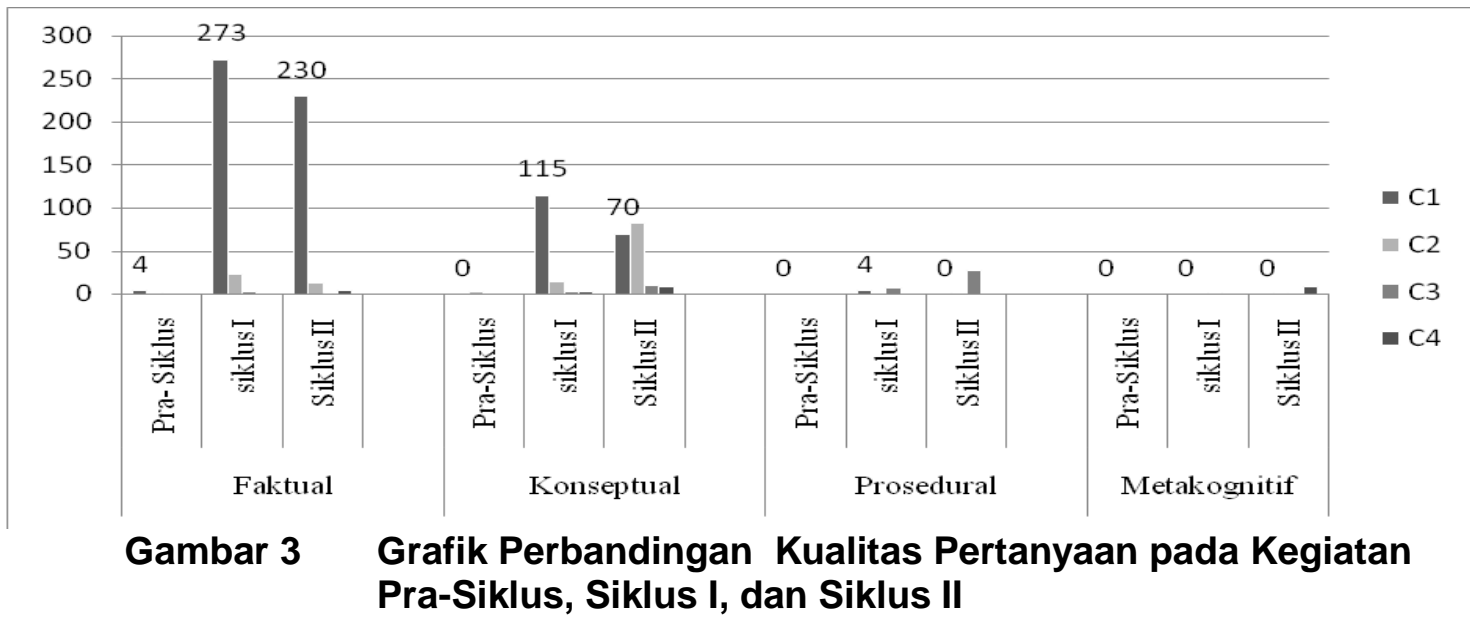


Keterampilan bertanya juga diukur melalui kualitas pertanyaan yang diajukan oleh siswa. Kualitas pertanyaan diukur menggunakan Taksonomi Bloom edisi revisi oleh Anderson \& Krathwohl (2015). Terjadi pemisahan antara dimensi pengetahuan dan dimensi proses berpikir kognitif. Dimensi pengetahuan terdiri dari pengetahuan faktual, konseptual, prosedural dan metakognitif. Dimensi proses berpikir kognitif yang digunakan dalam penelitian mencangkup tingkatan mengingat (C1), memahami (C2), menerapkan (C3), dan menganalisis (C4).

Peningkatan kualitas pertanyaan dari kegiatan observasi pra-siklus hingga siklus II sangat bervariasi. Secara keseluruhan, kualitas pertanyaan pada dimensi pengetahuan faktual, konseptual, prosedural dan metakognitif mengalami peningkatan dari kegiatan pra-siklus ke siklus I dan siklus II. Pertanyaan dimensi faktual tingkat C1 selalu mendominasi pada kegiatan pra-siklus, siklus I dan siklus II. Pertanyaan dimensi konseptual tingkat $\mathrm{C} 1$ paling sering muncul pada siklus I, sedangkan pertanyaan dimensi konseptual C2 paling sering muncul di siklus II. Pertanyaan dimensi prosedural yang tidak muncul pada kegiatan pra-siklus, telah muncul pada siklus I dengan tingkatan $\mathrm{C} 1$ dan $\mathrm{C} 3$, sedangkan di siklus II dengan tingkatan C2 dan C3. Pertanyaan dimensi metakognitif paling banyak muncul di siklus II.

Pertanyaan faktual paling banyak muncul pada kegiatan pra-siklus, siklus I maupun siklus II. Hal ini disebabkan oleh rentang usia siswa kelas III sekolah dasar (910 tahun) yang menurut Piaget termasuk ke dalam usia perkembangan kognitif operasional konkret. Pada tahap operasional konkret, pemikiran siswa masih bersifat konkret (faktual), kekal, klasifikasi, dan seriasi (Suparno, 2007). Oleh sebab itu, siswa lebih banyak bertanya mengenai apa yang mereka lihat, peristiwa yang sedang terjadi, maupun peristiwa yang terjadi dalam keseharian mereka. Pertanyaan faktual sering pula berupa pertanyaan tertutup, yaitu pertanyaan yang berkaitan dengan informasi yang terdapat pada buku teks atau suatu hal yang berfungsi untuk mengingat saja.

Pertanyaan konseptual muncul lebih sedikit daripada pertanyaan faktual pada kegiatan pra-siklus, siklus I maupun siklus II. Siklus I didominasi oleh pertanyaan konseptual C1, sedangkan siklus II didominasi oleh pertanyaan konseptual C2. Perbedaan jumlah pertanyaan ini dipengaruhi oleh karakteristik materi pada siklus I dan siklus II yang berbeda. Materi pada kegiatan siklus I yaitu jenis-jenis pekerjaan, sedangkan materi pada kegiatan siklus II adalah kegiatan jual beli. Materi pada siklus II bersifat lebih kompleks dan memerlukan pemahaman terhadap suatu konsep teori. Misalnya, kegiatan jual beli dapat melibatkan berbagai jenis pekerjaan, tempat kegiatan jual beli, maupun prosedur yang benar mengenai suatu cara. Materi kegiatan jual beli mendorong siswa untuk berpikir lebih luas dan kritis daripada materi jenis-jenis pekerjaan.

Pertanyaan prosedural paling banyak muncul pada kegiatan siklus II. Materi kegiatan jual beli juga mendorong siswa mengajukan pertanyaan yang berupa prosedur atau cara. Pertanyaan prosedural merupakan pertanyaan yang digunakan untuk memastikan prosedur yang diberikan atau menanyakan bagaimana suatu tugas akan dikerjakan (Chin, 2001). Media kartu bergambar tempat kegiatan jual beli juga mendukung siswa berpikir lebih luas mengenai prosedur yang dilakukan pada masingmasing tempat tersebut. Siswa menunjukkan rasa ingin tahunya dengan mengajukan berbagai pertanyaan tentang cara kerja suatu objek, seperti cara jual beli pada sebuah toko online.

Pertanyaan metakognitif merupakan pertanyaan yang menanyakan pengetahuan umum dan kognisi diri sendiri (Anderson \& Krathwohl, 2015). Pertanyaan metakognitif tidak muncul pada kegiatan pra-siklus tetapi muncul dengan jumlah sedikit pada siklus I dan siklus II. Pertanyaan metakognitif pada siklus I muncul sejumlah 1 
buah pertanyaan pada tingkat C3, sedangkan pada siklus II muncul 1 buah pertanyaan pada tingkat $\mathrm{C} 2$ dan 9 pertanyaan pada tingkat $\mathrm{C} 4$. Walaupun jumlah peningkatan pertanyaan dimensi metakognitif tidak signifikan, tetapi hal ini membuktikan dampak positif dari penerapan strategi pembelajaran learning cell. Siswa terlatih untuk berpikir tingkat tinggi dengan pertanyaan umum maupun kognisi dirinya sendiri.

Tentunya beragam jenis pertanyaan yang diajukan tiap siswa membuktikan bahwa penerapan strategi pembelajaran learning cell dapat meningkatkan kualitas pertanyaan yang diajukan siswa. Presentase siswa yang meningkatkan 1 tingkat kualitas pertanyaan juga sudah melebihi target yaitu 100\% dari 36 siswa. Masingmasing siswa mengalami peningkatan kualitas pertanyaan yang beragam sesuai dengan data baseline.

Peningkatan keterampilan bertanya dapat dioptimalkan melalui campur tangan guru. Menurut Chin (2001), siswa tidak selalu mampu mengajukan pertanyaan kognitif tingkat tinggi secara spontan kecuali guru memancing dengan memberikan penguatan kepada siswa berupa pemberian pertanyaan pula. Guru perlu mengajukan pertanyaan yang meningkatkan keingintahuan (curiosity) dalam diri siswa dan mengembangkan kemampuan mereka untuk belajar sepanjang hayat (Sani, 2014).

\section{SIMPULAN}

Berdasarkan hasil analisis data dan pembahasan maka disimpulkan bahwa penggunaan strategi pembelajaran learning cell dapat meningkatkan keterampilan bertanya pada pembelajaran IPS siswa kelas III SD Negeri Karangasem II tahun ajaran 2017/2018.

Berkaitan dengan hasil penelitian, peneliti mengajukan saran 1) bagi guru, disarankan untuk memberikan bimbingan di awal pembelajaran dengan tegas dan jelas sehingga siswa memahami langkah-langkah strategi learning cell dengan baik; 2) bagi sekolah, melakukan perbaikan sarana dan prasarana seperti penyediaan LCD proyektor untuk masing-masing kelas sehingga pembelajaran di kelas lebih efektif dan efisien; 3) bagi peneliti selanjutnya diharapkan mempersiapkan penelitian dengan matang dan waktu yang cukup lama agar penelitian dapat terlaksana dengan semaksimal mungkin

\section{DAFTAR PUSTAKA}

Anderson, L. W. \& Krathwohl, D. R. (2015). Kerangka Landasan Untuk Pembelajaran Pengajaran dan Asesmen, Revisi Taksoomi Bloom. Yogyakarta: Pustaka Belajar

Astuti, Meyria Silvi. (2015). Peningkatan Keterampilan Bertanya dan Hasil Belajar Siswa Kelas 2 SDN Slungkep 03 Menggunakan Model Discovery Learning. Scholaria: Jurnal Pendidikan Dan Kebudayaan, Vol 5 (1), 10-23

Barkley, E. E., Cross, K. P., Major, C. H. (2012). Collaborative Learning Techniques: Teknik-Teknik Pembelajaran Kolaboratif. Bandung: Nusa Dua

Chin, C. (2001). Learning in Science: What Do Students's Questioning Tell Us About Their Thinking. Education Journal, 29 (2), 85-103.

Daryanto. (2014). Pendekatan Pembelajaran Saintifik Kurikulum 2013. Yoyakarta: Gava Media.

Jayanti, Ummi Nur A. D. (2015). Penerapan Model Pembelajaran Guided Inquiry Untuk Meningkatkan Keterampilan Bertanya dan Berpendapat pada Materi Sistem Imunitas Siswa Kelas XI IIS-1 SMA Negeri 6 Surakarta Tahun Pelajaran 2014/2015. Prosiding SNPS (Seminar Nasional Pendidikan Sains), hlm. 1-14. 
Diperoleh tanggal 27 September 2017 dari http://jurnal.fkip.uns.ac.id/ index.php/snps/article/view/8311

Miles, Matthew B. dan A. Michael Huberman. (2014). Analisis Data Kualitatif: Buku Sumber Tentang Metode-Metode Baru. Jakarta: UI Press.

Nevers, S. T. \& Melrose, S. (2016). Commentary: Posing Questions To Support And Challenge- A Guide For Mentoring Staff. The Internet Journal of Allied Health Sciences and Practice, 14 (3), 1-10. Diperoleh tanggal 27 September 2017 dari http://nsuworks.nova.edu/ijahsp/vol14/iss3/2/

Sani, Ridwan Abdullah. (2014). Pembelajaran Saintifik untuk Implementasi Kurikulum 2013. Jakarta: PT Bumi Aksara

Siregar, Eveline \& Nara, Hartini. (2015). Teori Belajar dan Pembelajaran. Bogor: Ghalia Indonesia

Zaini, Hisyam, Munthe, B., Aryani, S. A. (2008). Strategi Pembelajaran Aktif. Yogyakarta: CTSD 